\title{
The Effects of Acquisition Targets, Diversification and Market Power on Cost Efficiency: Evidence form Taiwanese Banks
}

\author{
Ying-Hsiu Chen ${ }^{1} \&$ Meng-Chun $\mathrm{Kao}^{2}$ \\ ${ }^{1}$ Department of Food and Beverage Management, Yuanpei University of Medical Technology, Taiwan \\ ${ }^{2}$ Department of Business Administration, Yuanpei University of Medical Technology, Taiwan \\ Correspondence: Meng-Chun Kao, Department of Business Administration, Yuanpei University of Medical \\ Technology, Taiwan. Tel: 886-3-538-1183 ext. 8607. E-mail: ruth@ mail.ypu.edu.tw
}

Received: November 19, 2014

Accepted: November 28, 2014

Online Published: January 25, 2015

doi:10.5539/ibr.v8n2p71

URL: http://dx.doi.org/10.5539/ibr.v8n2p71

\begin{abstract}
This study employs a stochastic frontier approach to explore the impacts of acquisition targets, diversification and market power on cost efficiency and compare scale economies, and cost complementarity for 44 banks in Taiwan for the period from 1997 to 2006. The empirical results show that M\&As operates with deterioration in the cost efficiency regardless of bank to bank mergers as well as bank to credit union mergers. The higher level of diversification decreases the cost efficiency; however, the banks can improve the cost efficiency when they increase the market power of loans. We also find that the banks operate at economies of scale but the cost complementarity does not exist in the outputs of investment and loans.
\end{abstract}

Keywords: mergers and acquisitions, diversification, market power, cost efficiency

\section{Introduction}

Intense competition and financial deregulation have prompted a wave of the mergers and acquisitions (M\&A) in the banking industry throughout the world, starting in the U.S. and reaching Europe and Japan. The major part of financial systems had removed the primary product-based barriers in the financial service sectors. Meanwhile, diversification has accompanied the financial sector consolidation trend. M\&A has been the preferred approach for U.S., European, and Asian financial institutions to expand into new financial areas. The typical surviving bank is larger, more diversified, and operates in more places than ever before (DeYoung et al., 2009). Taiwanese banking industry also has been impacted by the surge of bank consolidation through M\&A. With the government engaged in building up Asia-Pacific Financial Center (APFC) and joining the WTO in 2002, Taiwan has been forced to open its financial market through financial deregulation to attract foreign investors and financial institutions. The explosive growth in banking industry has resulted in deteriorating banks' asset quality and squeezing profit margins. The authority has taken various measures and restructuring programs to improve the financial industry. The Financial Institutions Merger Act and Financial Holding Company Act were passed in 2000 and 2001 respectively. Financial institutions are allowed to merge with others in the industry or cross industries and each other. Followed by the Second Financial Restructuring was passed in 2004 to speed up M\&A among financial institutions. M\&A of financial institutions have become a trend for Taiwanese financial industry. Financial institutions may conduct M\&A, diversify across product lines, increase their market shares to achieve economies of scope or scale, and consequently improve their competitiveness.

Numerous studies examine the effects of M\&A in the U.S. and European financial markets. Nevertheless, the impact of consolidation on performance is mixed. Although DeYound et al. (2009) proposed that the mixed findings could be contributed to the different methodologies and time period being selected, this study further considers the impact of different acquisition targets on cost efficiency. Taiwan is a bank-oriented financial market and thus we examine the commercial banks rather than the consolidated financial holding company (FHC). For bank mergers in Taiwan, most of targets are the banking sector or credit unions. Credit unions are financial cooperatives and provide financial services to their members. While credit unions greatly expand their field of their membership into traditional commercial banking areas, such as small business service and lending, these product offerings have blurred the lines of demarcation between credit unions and mainstream financial service. Credit unions may serve as the competitors to commercial banks. Against the financial industry consolidation, credit unions can be viewed as the targets in the bank merging activities. In this study, we attempt 
to differentiate these impacts of bank to bank mergers and bank to credit union mergers on the cost efficiency.

Furthermore, we also wonder whether diversification and market power would lead to efficiency gains. Prior studies for the impact of diversification on bank performance still remain inconclusive. Diversified banks can benefit from using firm-specific resources to extend a competitive advantage across products and geographic regions (Bodnar et al., 1997), improving resource allocation through internal capital market (Stein, 1997), and gaining the economies of scale and scope (Teece, 1982). On the other hand, Lang and Stulz (1994) and Berger and Ofek (1995) stated that diversification across different business segments tends to reduce firm value. Rime and Stiroh (2003) found no evidence of cost efficiencies in their study of product diversification acquisitions. Stiroh and Rumble (2006) found diversification benefits could be offset by the volatility of non-interest incomes. Some studies have found diversification discounts in financial services firms (Laeven and Levine, 2007; Schmid \& Walter, 2009).

Meanwhile, the motive of bank M\&A is to acquire the greater market power to increase the concentration of merging firms that can result either in higher prices or profits. According to the relative market power hypothesis and Berger (1995) the positive relationship between market power and efficiency seems to exist. Nevertheless, banks may seek growth by M\&A to obtain "too-big-to-fail" status. Large size sometimes reflects that managers are free from the intense competition. Berger and Hannan (1998) proposed the quiet life hypothesis that managers would relax their effort to maximize efficiency resulting from agency problems when the marker power is higher whereas Maudos and Guevara (2007) found the adverse results. The extant literature provides no consistent evidence regarding whether the merging banks benefit from different acquisition targets, or whether the efficiency gains benefit from diversification or market power.

Our results show that both bank to bank mergers and bank to credit union mergers are negatively related to cost efficiency. The higher level of diversification would not obtain the benefits, indicating that these gains could be offset by the extra costs from the diversity. However, the banks can improve the cost efficiency when they increase the market power of loans. Consistent with Maudo and Guevara (2007), the quiet life hypothesis (Berger and Hannan, 1998) are rejected, indicating that banks with greater market power in loans can possess superior cost efficiency. The cost efficiency could be improved by the reduction of diversification and the ratio of non-performing loans or the increase of market power of loans and financial development. The contributions of this paper are as follows. First, there are scant studies to explore the relationship among different acquisition targets, diversification, market power and efficiency simultaneously in the emerged financial market despite growing research on the M\&A effects.

This study applies the one step SFA model of Battase and Coelli (1995) to identify the existence and the magnitude of efficiency gains from targets, diversification and market power. Second, the acquisition targets are divided into banks and credit unions. In the focused mergers, prior studies pay attention to bank to bank mergers (DeLong, 2001; Diaz et al., 2004; Cornett et al,. 2006) whereas bank to credit union mergers are less likely to explore. However, Taiwanese credit unions with less profitability or poor financial structure are more likely to be acquisition targets in financial consolidation. In our sample, the number of bank to credit unions mergers (19) is higher than that of bank to bank mergers (11). The effect of target credit unions on efficiency in merger activities cannot be overlooked. Finally, our sample includes all commercial banks in Taiwan. The sample period covers 10 years and contrary to prior studies that focused mostly on large banks (Al-Sharkas et al., 2008).

The rest of this paper is structured as follows. Section 2 reviews the relevant literature on the effects of M\&A, diversification and market power on efficiency. Section 3 discusses the methodology, and variable definitions. Section 4 describes the sample and data. Section 5 presents the empirical results. Finally, section 6 contains conclusions and recommendations.

\section{Literature Review}

Many banks engage in M\&A activities to increase diversification, enlarge market power, achieve economies of scale or scope and finally obtain the efficiency gains. However, the empirical evidence for US and European banking markets does not achieve consensus. Some studies provided evidence that bank mergers have possessed higher economic efficiency (or X-efficiency), cost efficiency or profit efficiency than non-mergers (DeYoung, 1993; Shaffer, 1993; Akhavein el al., 1997; Rhoades, 1998; Kohers et al., 2000; Cornett et al., 2006; Knapp et al., 2006; Al-Sharkas et al., 2008). Other studies supported the opposite conclusion (Berger \& Humphrey, 1992; Srinivasan, 1992; Peristiani, 1997; Berger et al., 1999; Hughes et al., 2001). Berger and Humphrey (1992) found that on average the mergers were not successful in improving cost efficiency, attributed to diseconomies of scale and Srinivasan (1992) also found similar results, particularly when non-interest expenses were not reduced after mergers. Hughes et al. (2001) proposed that the merger could lead to diseconomies without considering capital 
structure and risk-taking. Potential gains may be offset by managerial inefficiencies or problems in integrating systems.

For the impact of acquisition targets, Houston et al. (2001) found that both targets and acquirers of focused mergers could obtain the gains and acquirers of focused mergers are expected to reduce costs faster and more dramatically than non focused ones. Similarly, DeLong (2001) noted that efficient acquirers tend to improve the efficiency of the targets more than other acquirers and focused mergers with respect to product offerings or geography enhance stockholder value, supported the results by Cornett et al. (2006). Diaz et al. (2004) and Altunbas and Marques (2008) also found that focus deals tend to perform better relative to non-focused bank mergers. In addition, some studies suggested that the potential post-merger performance gains exist because the cost-efficient banks tend to acquire their less inefficient counterparts (Shaffer, 1993; Hannan \& Pilloff, 2006).

However, less attention has been given to credit unions in the focused mergers. Many credit unions provide financial services similar to those of banks such as interest-bearing business checking accounts and loans, and bankers' acceptance. Meanwhile, the business of credit unions is specialized in the loan market such as commercial loans, agricultural loans, and venture capital loans. In recent years, the number of credit unions in Taiwan has declined mainly due to financial consolidation. Banks that merge with credit unions can expand their market shares of loans. There are numerous merges between banks and credit unions in Taiwan, but few mergers among credit unions. Credit unions could be attractive choices of acquisition targets. However, we are unaware of any studies that explore the impact of bank to credit union mergers. Our paper attempts to examine the impact of different acquisition targets on efficiency.

Diversification can be achieved faster through M\&A activities. Prior studies for the impact of diversification on bank performance still remain inconclusive. Lang and Stulz (1994) suggested that growth via diversification is constrained to internal growth opportunities. Many studies (Berger \& Ofek, 1995; Shin \& Stulz, 1998) pointed out the deficiencies associated with internal capital markets. Berger and Ofek (1995) found that overinvestment and cross subsidization contributed to the value loss. Shin and Stulz (1998) also found that diversified firms tend to practice socialism in internal markets by treating divisions equally in resource allocation consistent with the findings of Rajan et al. (2000) and Scharfstein and Stein (2000). Stiroh and Rumble (2006) represented the dark side of diversification that revenue diversification were not associated with better performances because fee-based activities were more volatile but not necessarily more profitable than traditional interest earning activities Laeven and Levine (2007) showed that diversified banks experience diversification discount compared to specified ones because increasing agency costs outweigh benefits of economies of scope. Schmid and Walter (2009) also found that the diversification causes the discount. Similarly, Berger et al. (2010) found that diversification of Chinese banks is related to lower profits and higher costs. On the other side, some studies argued that measurement problem (Whited, 2001), data problems (Villalonga, 2004), sample selection biases (Graham et al., 2002), and failure to control for the endogeneity of the diversification decision (Campa \& Kedia, 2002) have driven the previous results. Furthermore, Elsas et al. (2010) utilized several alternative measures for bank diversification and found the diversification premium.

Banks may seek fast growth via M\&A activities to obtain market power effects, with lower deposit rates and higher loan rates in more concentrated markets. De Guevara et al. (2005) found that consolidation drove down marginal costs faster than output prices, suggesting an increase in market power. According to the relative market power hypothesis (Shepherd, 1982), individual market share is utilized to the proxy variable for assessing market power and asserted that only banks with large market shares and well differentiate products would possess market power in pricing these products to earn supernormal profits finally. Berger (1995) also stated that the superior efficient banks assume to gain the greater market shares. Thus, the relationship between market power and efficiency seems to be positive. Nevertheless, Berger and Hannan (1998) proposed quiet hypothesis that the higher market power, the lower the effort of managers to maximize efficiency, indicating a negative relationship between market power and efficiency. When banks compete in a higher concentration market, monopoly power allows managers to relax their efforts to keep costs under control. The sustained pursuit of market power raises costs and reduces cost efficiency. Meanwhile, market power allows managers to engage in personal objectives (such as maximizing their own utility or building their empire, etc.) other than profit maximization. However, Maudos et al. (2007) applied the Lerner index of market power to explore the relationship between market power and efficiency in EU banking. Their results are against the quiet life hypothesis, indicating the positive relationship between market power and cost efficiency. Therefore, the impact of marker power on efficiency is mixed.

Importantly, the existing banking literature on the impact of acquisition targets, diversification and market power on efficiency is examined respectively and is heavily concentrated in US and European banking markets, while 
leaving these issues in emerging economies largely unexamined. Our paper attempts to fill this gap in the literature by utilizing the model of Battase and Coelli (1995) to explore the impact of these determinants, acquisition targets, diversification and market power on efficiency simultaneously in Taiwanese banking industry.

\section{Model Specification}

The SFA was independently proposed by Aigner et al. (1977) and Meeusen and van den Broeck (1977) for cross sectional data. Battase and Coelli (1995) proposed a technical inefficiency effects model for panel data, to investigate the determinants of technical inefficiencies among firms by one-step procedure. For an introduction to SFA methodology, see Coelli et al. (1998) has explicit illustrations. As pointed out by Wang and Schmidt (2002), the one-step estimators generally performed quite well in finite sample, whereas both estimators of the two-step procedure were seriously biased. This paper employs the specific model of Battase and Coelli (1995) to examine the impacts of firm-specific factors on Taiwan's bank efficiency, but extends the Cobb-Douglas production frontier to the translog cost frontier function, and allows the inefficiency to change in some persistent pattern over time.

\subsection{The Translog Cost Frontier Function}

Suppose that there are $\mathrm{N}$ different firms under consideration that face their input prices and pursue the cost minimization objective for a given amount of outputs. The stochastic cost frontier model for each bank $\mathrm{i}$ at time $\mathrm{t}$ can be written as:

$$
T C_{i t}=f\left(X_{i t} ; \beta\right) e^{v_{i t}+u_{i t}}
$$

where subscripts $\mathrm{i}=1, \ldots, \mathrm{N}$ and $\mathrm{t}=1, \ldots, \mathrm{T}$ stand for bank and time, respectively; $T C_{i t}$ is the realized total cost; $X_{i t}$ is a vector for outputs and input prices; and $\beta$ is a vector of unknown technology parameters to be estimated. The composed error term is decomposed into random variable, $v_{i t}$, and non-negative random variable, $u_{i t}$.

Following Battase and Coelli (1995), terms $v_{i t}$ is assumed to be i.i.d. $\mathrm{N}\left(0, \sigma_{v}^{2}\right)$, independent of the $v_{i t}$, which accounts for the cost of inefficiency in production and is obtained by truncation of the $\mathrm{N}\left(g_{i t}, \sigma_{u}^{2}\right)$ distributed, where

$$
g_{i t}=z_{i t} \delta
$$

where $z_{i t}$ is an $\mathrm{M} \times 1$ vector of observable explanatory variable which may influence the inefficiency of a firm; and $\delta$ is a $1 \times \mathrm{M}$ vector of unknown parameters to be estimated. According to Battese and Corra (1977), terms of the variance parameters are expressed as $\sigma^{2}=\sigma_{v}^{2}+\sigma_{u}^{2}$ and $\gamma=\sigma_{u}^{2} /\left(\sigma_{v}^{2}+\sigma_{u}^{2}\right)$ where the parameter $\gamma$ must lie between 0 and 1 .

This paper adopts a translog cost frontier functional forms involving two outputs and three input prices to be the appropriate model for the analysis of the data available on 44 domestic commercial banks in Taiwan. The translog function is a flexible form because it offers a second-order approximation to the true but unknown function. According to the regularity conditions required by microeconomic theory, the homogeneity constraint is imposed on the cost function first, and other properties can be checked once the parameters have been estimated. Equation (3) is further defined as:

$$
\begin{aligned}
& \ln \left(T C_{i t} / P_{1 i t}\right)=\alpha_{0}+\sum_{n=1}^{2} \alpha_{n} \ln y_{n i t}+\sum_{k=2}^{3} \lambda_{k} \ln \left(P_{k i t} / P_{1 i t}\right)+0.5 \times \sum_{n=1}^{2} \sum_{r=1}^{2} \eta_{n r} \ln y_{n i t} \ln y_{r i t} \\
& \quad+0.5 \times \sum_{k=2}^{3} \sum_{s=2}^{3} \theta_{k s} \ln \left(P_{k i t} / P_{1 i t}\right) \ln \left(P_{\text {sit }} / P_{1 i t}\right)+\sum_{n=1}^{2} \sum_{k=1}^{3} \phi_{n k} \ln y_{n i t} \ln \left(P_{k i t} / P_{1 i t}\right)+u_{i t}+v_{i t}
\end{aligned}
$$

where $T C_{i t}$ is the observed cost of production for the i-th bank at time $\mathrm{t}$; Following the intermediation approach, the output entities, $\mathrm{y}_{1}$ and $\mathrm{y}_{2}$, are investments and loans, respectively; $\mathrm{P}_{\mathrm{k}}$ denotes the input price of the k-th input where the three inputs are labor, fund, and physical capital.

In Equation (3), we divide the observed total costs and each of the input prices by the price of labor, $\mathrm{P}_{1}$, to assure the linear homogeneity of the cost function in the factor prices. The unknown technology parameters of cost function, $\alpha_{0}, \alpha_{n}, \lambda_{k}, \theta_{k s}$ and $\varphi_{n k}$, can be estimated using the maximum likelihood method (MLE). $u_{i t}$ is the proportion by which the $\mathrm{i}$-th bank could have reduced its cost to obtain minimal cost at time $t$, given the same level of outputs. The measures of cost efficiency (CE) or overall economic efficiency (EE) is derived by the ratio of frontier minimum cost to observed cost, which can be calculated as $\mathrm{CE}=\exp (-\mathrm{u})$ and is bounded between 0 and 1 . 
In order to analyze the impacts of the acquisition targets, diversification and market power on bank efficiency, Equation (2) is further defined by

$$
g_{i t}=\delta_{0}+\delta_{1} M A_{i t}^{b}+\delta_{2} M A_{i t}^{c}+\delta_{3} D I V_{i t}+\delta_{4} M P_{i t}+\delta_{5} P^{2} u b l i c_{i t}+\delta_{6} A Q_{i t}+\delta_{7} F D_{i t}+\delta_{8} t+\delta_{9} t^{2}
$$

where $\mathrm{i}$ indexes the banks; $\mathrm{t}$ is the time index; $M A^{b}$ is a dummy variable valued at 1 for bank to bank mergers and zero otherwise; $M A^{c}$ is a dummy variable with 1 for bank to credit union mergers and zero otherwise; DIV represents the degree of diversification in a bank's net operating revenue and is computed as the measurement in Stiroh and Rumble (2006). MP denotes loan market share of individual bank which is a proxy for assessing market power, according to the relative market power hypothesis.

Additionally, a few control variables are included in Equation (4) to take into account the influence of other potential variables, including institutional differences, specifics of individual banks and Taiwan's financial environment. Public is a dummy variable with 1 if government-owned shares are more than half of total shares in a bank and zero otherwise. $A Q$ is a proxy for asset quality of a bank and is computed as the ratio of non-performing loans to total loans, and $F D$ denotes the degree of financial development which is measured as the ratio of production value of the financial services industry to gross domestic product in Taiwan. Time trend term (t) and its squared term $\left(\mathrm{t}^{2}\right)$ are also included to allow for the inefficiency to change over time, and $\mathrm{t}$ is a time indicator valued at 1 to 10 for 1997 to 2006, the sample years, respectively.

\subsection{Formulations of the Scale Economies and Cost Complementarity}

If the estimated cost function satisfies the other regularity conditions of microeconomic theory given parameter estimates, we can use these estimated parameters to examine whether individual bank has the properties of scale economies and cost complementarities for multiple outputs in production as in Diewert and Wales (1987) and Jagtiani et al. (1995). Overall scale economies (OSE) can be expressed in the following form:

$$
O S E=T C^{*}(Y, P) / \sum_{n=1}^{2} y_{n} T C_{n}^{*}(Y, P)
$$

where $\mathrm{TC}^{*}(\mathrm{Y}, \mathrm{P})$ is the cost function; $\mathrm{Y}$ and $\mathrm{P}$ are vectors of outputs and input prices, respectively; $\mathrm{y}_{\mathrm{n}}$ is the $n$th output produced by a bank; and $\mathrm{TC}_{n}^{*}=\partial \mathrm{TC}^{*} / \partial y_{n}, \mathrm{n}=1,2$. If $O S E>1$, returns to scale are increasing, implying scale economies, i.e., that the bank's product mix could be produced at lower average cost by increasing the scale of output. If $O S E$ is equal to, or less than 1 respectively indicates constant returns to scale, or scale diseconomies.

A cost complementarity exists between two products if the marginal cost of producing one product declines when it is produced jointly with the other, that is product-specific economies of scope can be realized from joint production (Clark, 1988). The cost complementarity between $\mathrm{y}_{1}$ and $\mathrm{y}_{2}\left(\mathrm{COMP}_{12}\right)$ is specified as follows:

$$
C O M P_{12}=\partial^{2} T C^{*}(Y, P) / \partial y_{1} \partial y_{2}
$$

where $\mathrm{TC}^{*}(\mathrm{Y}, \mathrm{P}), \mathrm{y}_{1}$ and $\mathrm{y}_{2}$, are the cost function, investments and loans, respectively. If $\mathrm{COMP}_{12}<0$, the marginal cost producing $\mathrm{y}_{1}$ is reduced by enhancing the level of $\mathrm{y}_{2}$, implying that there is a cost complementarity between investments and loans, and product-specific economies of scope exists in the bank. To evaluate these measures, we use the sample mean values of input prices and output levels.

\section{Data Description}

The sample is an unbalanced panel of, 44 domestic commercial banks during the period from 1997 to 2006 , totaling 399 observations. There are 11 cases of bank to bank mergers and 19 cases of bank to credit union mergers. All variables are inflation-adjusted to the base year 2001. The financial data is obtained from the bank of Taiwan Economic Journal's financial database and other official sources, such as relevant publications of the central bank and the ministry of finance bureau of monetary affairs. Table 1 is the sample statistics.

Ttotal costs (TC) are the sum of the costs of labor, funds and physical capital. Investments (y1) include government and corporate securities and stocks, and loans (y2) include various short- and long-term loans. Number of labor $\left(\mathrm{x}_{1}\right)$ represents the $\mathrm{h}$ number of full-time-equivalent employees, funds represent all kinds of deposits and borrowed funds $\left(\mathrm{x}_{2}\right)$, and physical capital represents net physical capital $\left(\mathrm{x}_{3}\right)$. Input price of $\mathrm{x}_{1}$ is calculated as the employees' compensation divided by the number of $x_{1}$, input price of $x_{2}$ is calculated as all interest payments divided by the dollar value of $\mathrm{x}_{2}$, and Input price of $\mathrm{x}_{3}$ is calculated by dividing occupancy and fixed asset expenditures through $\mathrm{x}_{3}$.

Degree of diversification (DIV) represents the degree of diversification in a bank's net operating revenue and computed as the measurement $D I V=1-\left(S H_{N E T}^{2}+S H_{N O N}^{2}\right)$ where $S H_{\mathrm{NET}}$ is the share of net operating revenue from net interest sources and $S H_{\mathrm{NON}}$ is the share of net operating revenue from non-interest sources. Market power (MP) denotes loan market share of individual bank; non-performing loans ratio (AQ) is a proxy for asset 
quality of a bank and is computed as the ratio of non-performing loans to total loans, and degree of financial development (FD) is the degree of financial development which is measured as the ratio of production value of the financial services industry to gross domestic product in Taiwan.

Table 1 shows that for the outputs, loans (y2) are the main product of the overall banks, which are about more than four times as much as the investment (y1) on average. The input item, funds (x2) appears to be the most important factor of production. There are also a large variability in the input and output items. Furthermore, the degree of diversification (DIV) of merging banks is larger than the total mean $(28.19 \%$ ), up to $32.46 \%$ after mergers. For bank to credit union mergers, the NPL ratio and DIV increase to $7.05 \%$ and $27.79 \%$ after mergers, respectively.

Table 1. Sample statistics

\begin{tabular}{lccc}
\hline \multicolumn{1}{c}{ Variables } & & Mean & Standard Deviation \\
\hline Total costs & $(\mathrm{TC})$ & $21,068.30$ & $21,628.60$ \\
Investments & $\left(\mathrm{y}_{1}\right)$ & $75,465.03$ & $104,880.54$ \\
Loans & $\left(\mathrm{y}_{2}\right)$ & $336,310.88$ & $355,502.36$ \\
Number of labor & $\left(\mathrm{x}_{1}\right)$ & 2,690 & $2,106.64$ \\
Funds & $\left(\mathrm{x}_{2}\right)$ & $439,550.89$ & $475,805.87$ \\
Physical Capital & $\left(\mathrm{x}_{3}\right)$ & $12,573.84$ & $15,992.33$ \\
Input price of $\mathrm{x}_{1}$ & $\left(\mathrm{P}_{1}\right)$ & 1.0466 & 0.3347 \\
Input price of $\mathrm{x}_{2}$ & $\left(\mathrm{P}_{2}\right)$ & 0.0319 & 0.0175 \\
Input price of $\mathrm{x}_{3}$ & $\left(\mathrm{P}_{2}\right)$ & 0.6817 & 0.8025 \\
Degree of diversification $(\%)$ & $(\mathrm{DIV})$ & 28.1938 & 11.0596 \\
Market power $(\%)$ & $(\mathrm{MP})$ & 2.2800 & 2.3899 \\
Non-performing loans ratio $(\%)$ & $(\mathrm{AQ})$ & 5.6756 & 7.0086 \\
Degree of financial development & $(\mathrm{FD})$ & 8.5040 & 0.4560 \\
\hline
\end{tabular}

Note. Variables are reported in NT\$ millions.

\section{Empirical Results}

In the first subsection, we present the coefficient estimates of the stochastic cost frontier function and of the inefficiency function for Taiwan's banking samples during the period considered. The second subsection measures the cost efficiency, the scale economies and the cost complementarity of two outputs for each sample bank.

\subsection{Coefficient Estimates of the Translog Cost Function and Inefficiency Function}

Table 2 reports the parameter estimates of Translog cost frontier function by MLE, and more than half of parameter estimates attain statistical significance at least at the $10 \%$ level. In order to examine regularity conditions by microeconomic theory, the three cost shares, marginal costs of two outputs and Hessian matrixes are calculated for each sample observation, given estimated parameters in Table 2. These calculated results are not shown to save space, but are available upon request to the authors. Most of estimated signs for the sample observations are found to be consistent with the theory, implying parameter estimates of cost function are well representative to describe an average bank's production technology and cost structure.

The existence of cost inefficiency is investigated by a likelihood ratio test of the null hypothesis that there is no cost inefficiency, as in Coelli (1995). The likelihood ratio test statistic is calculated as $L R=-2\left[\log \left(\mathrm{L}_{0}\right)-\log \left(\mathrm{L}_{1}\right)\right]$, where $\log \left(\mathrm{L}_{0}\right)$ is the $\log$-likelihood value under the null hypothesis that $\gamma=0$, and $\log \left(\mathrm{L}_{1}\right)$ is the $\log$-likelihood value assuming the null is false. These two log-likelihood values are estimations of the stochastic frontier using MLE and ordinary least squares (OLS) method, respectively, and the likelihood ratio test statistic will has asymptotic distribution equal to a mixture of chi-square distribution.

The LR of 80.054 is greater than the critical value for a test of $1 \%$, indicating the null hypothesis is rejected and cost inefficiency indeed exists in the stochastic frontier model. The parameter estimates of Table 2 are then used to calculate the partial cost elasticities for each output and input price. Evidence is found that if the whole 
banking increases $1 \%$ of investment or loan produce, then it enhances $0.07 \%$ or $0.86 \%$ of the potential cost, respectively. In terms of input prices, the price of funds has a greater impact on potential cost than the prices of labor and physical capital. On average, if banking increases $1 \%$ of the price of funds, the potential cost goes up $0.58 \%$, whereas $1 \%$ of the price of labor or physical capital increases $0.29 \%$ or $0.21 \%$ of the potential cost, respectively.

Table 2. Parameter estimates of the Translog cost frontiers

\begin{tabular}{|c|c|c|}
\hline Independent Variables & Estimates & Standard Errors \\
\hline Intercept & $39.8028 * * *$ & 1.0013 \\
\hline $\ln y_{1 t}$ & -0.3450 & 0.4897 \\
\hline $\ln y_{2 t}$ & $-2.6621 * * *$ & 0.4133 \\
\hline $\ln \left(P_{2} / P_{1}\right)_{t}$ & $2.1619 * * *$ & 0.7359 \\
\hline $\ln \left(P_{3} / P_{1}\right)_{t}$ & $-1.0851 * *$ & 0.5466 \\
\hline $0.5\left(\ln y_{1 t}\right)^{2}$ & 0.0341 & 0.0430 \\
\hline $0.5\left(\ln y_{2 t}\right)^{2}$ & $0.1144 * * *$ & 0.0425 \\
\hline $\ln y_{1 t} \ln y_{2 t}$ & 0.0328 & 0.0431 \\
\hline $0.5\left[\ln \left(P_{2} / P_{1}\right)_{t}\right]^{2}$ & $0.2475 * * *$ & 0.0917 \\
\hline $0.5\left[\ln \left(P_{3} / P_{1}\right)_{t}\right]^{2}$ & $0.0604 *$ & 0.0360 \\
\hline $\ln \left(P_{2} / P_{1}\right)_{t} \ln \left(P_{3} / P_{1}\right)_{t}$ & $-0.1551 * * *$ & 0.0483 \\
\hline $\ln y_{1 t} \ln \left(P_{2} / P_{1}\right)_{t}$ & $0.0771 *$ & 0.0401 \\
\hline $\ln y_{1 t} \ln \left(P_{3} / P_{1}\right)_{t}$ & -0.0014 & 0.0316 \\
\hline $\ln y_{2 t} \ln \left(P_{2} / P_{1}\right)_{t}$ & $-0.0783 *$ & 0.0428 \\
\hline $\ln y_{2 t} \ln \left(P_{3} / P_{1}\right)_{t}$ & 0.0076 & 0.0379 \\
\hline$\sigma^{2}\left(=\sigma_{u}^{2}+\sigma_{v}^{2}\right)$ & $0.1404 * * *$ & 0.0112 \\
\hline$\gamma\left(=\sigma_{u}^{2} /\left(\sigma_{u}^{2}+\sigma_{v}^{2}\right)\right)$ & $0.4230 * * *$ & 0.0615 \\
\hline log likelihood & \multicolumn{2}{|c|}{-115.8462} \\
\hline LR test of the one-sided error & \multicolumn{2}{|c|}{80.0540} \\
\hline
\end{tabular}

Note. Variable definitions are similar with the above-mentioned.

${ }^{* * *}$ significant at the $1 \%$ level, ${ }^{* *}$ significant at the $5 \%$ level, and ${ }^{*}$ significant at the $10 \%$ level.

Table 3 represents the coefficient estimates of the inefficiency function. The results show that both bank to bank mergers $\left(\mathrm{MA}_{b}=0.7779\right)$ or bank to credit union mergers $\left(\mathrm{MA}_{c}=0.2183\right)$ are negatively related to cost efficiency significantly. M\&A leads to decrease cost efficiency attributed to diseconomies of scale consistent with the results reported by Berger and Humphrey (1992), Srinivasan (1992) and Hughes et al. (2001). Differing from the prior studies (Diaz et al., 2004; Cornett et al., 2006; Altunbas \& Marques, 2008), interbank mergers obtain the greater negative impact on cost efficiency than that of bank to credit union mergers. This could be the reason that the costs of interbank mergers are higher and the problems in integrating systems (such as personnel integration, system integration issues) have not been realized until several years. (Diaz et al., 2004; Campa \& Hernando, 2006; Sherman \& Rupert, 2006).

Second, the impact of degree of diversification on cost efficiency (DIV $=0.0056$ ) is significantly negative, consistent with the prior studies (Rime \& Stiroh, 2003; Stiroh \& Rumble, 2006; Laeven \& Levine, 2007; Schmid $\&$ Walter, 2009; Berger et al., 2010). The result shows that diversification would not obtain the benefits of economies scale and scope resulting from the deficiencies associated with internal capital markets (Berger \& Ofek, 1995; Shin \& Stulz, 1998; Rajan et al., 2000; Scharfstein \& Stein, 2000), or increasing agency costs (Laeven and Levine, 2007). Third, the market power is positively related to cost efficiency significantly ( $\mathrm{MP}=$ -0.2247). Consistent with Maudo and Guevara (2007), the quiet life hypothesis (Berger \& Hannan, 1998) are rejected, indicating that banks with greater market power in loans can possess superior cost efficiency. According to De Guevara et al. (2005), the gains of market power can be obtained resulting from marginal costs driving down faster than output prices when banks increase their loans market shares. 
The control variable, government-controlled banks (Public $=0.5177$ ), is negative related with cost efficiency, indicating that government ownership on banking is efficiency decreasing consistent with the result of the prior study (Weintraub \& Nakane, 2005). Government-controlled banks have pursued non-economic objectives, rather than focusing exclusively on profit maximization. Megginson (2005) stated that government ownership would be inefficient by design. Since government-controlled banks have to respond to political masters such as inadequate funding to sector s and groups with low financial but high social returns and a desire to use banks as tools for political patronage and advantage, wide divergences from profit-maximizing behavior are possible. La Porta et al. (2002) found evidence to support the political view of stat ownership of banks. The result provides evidence to support that Taiwanese government launched bank privatization programs. Finally, other control variables are consistent with our expectations. The $N P L$ ratio is significantly negative related to cost efficiency $(\mathrm{AQ}=0.0097$ ) while that of financial development is significantly positive $(\mathrm{FD}=-0.2625)$, indicating that banks possess better asset quality and sound financial development could improve cost efficiency. In the time trend term ( $\mathrm{t}$ and $\left.\mathrm{t}^{2}\right)$, even though the estimator of $t$ is positive with inefficiency insignificant while that of $t^{2}$ is negative significantly, indicating that the post mergers improvements could take a while to appear.

Table 3. Coefficient estimates of the inefficiency function

\begin{tabular}{clcc}
\hline Variables & Estimates & Standard Errors & Effects on cost efficiency \\
\hline$\alpha_{0}$ & $1.9906 *$ & 1.1716 & negative \\
$\mathrm{MA}_{\mathrm{b}}$ & $0.7779 * * *$ & 0.1650 & negative \\
$\mathrm{MA}_{\mathrm{c}}$ & $0.2183 * * *$ & 0.0740 & negative \\
$\mathrm{DIV}$ & $0.0056 *$ & 0.0033 & negative \\
$\mathrm{MP}$ & $-0.2274 * * *$ & 0.0457 & positive \\
Public & $0.5177 * * *$ & 0.1188 & negative \\
$\mathrm{AQ}$ & $0.0097 * *$ & 0.0046 & negative \\
$\mathrm{FD}$ & $-0.2625 *$ & 0.1360 & positive \\
$\mathrm{t}$ & 0.1013 & 0.0691 & insignificant \\
$\mathrm{t}^{2}$ & $-0.0128 * *$ & 0.0055 & positive
\end{tabular}

Note. ${ }^{* * *}$ significant at the $1 \%$ level, ${ }^{* *}$ significant at the $5 \%$ level, and ${ }^{*}$ significant at the $10 \%$ level.

\subsection{Evaluations of Cost Efficiency, Scale Economies and Cost Complementarity}

Table 4 reports the results of cost efficiency, scale economies and cost complementarity. In terms of overall banks, the average CE score is only 0.7773 indicating the observed cost is about 1.29 times as high as the potential cost on average. When cost inefficiency can be improved, the cost savings are up to $22.27 \%$. Furthermore, the sample is partitioned into two sub-samples by the criteria of the acquisition targets and ownership of banks. The average cost efficiency of merging banks (0.6954) is lower than that of target banks (0.7624) and the merging banks are less efficient in the post mergers corresponding with the previous results. The reason could be that the degree of diversification of merging banks is up to $32.25 \%$ in the post mergers, suggesting that the costs of diversification outweigh the benefits of mergers.

Meanwhile, the cost efficiency of merged banks is higher than that of merging banks. Thus, superior efficient banks with smaller market shares appear to be attractive acquisition targets. Similarly, bank to credit union mergers are less efficient in the post mergers, indicating that mergers cannot improve cost efficiency. The inefficiency results from the deterioration of asset quality and diversification discount. In terms of ownership structure, government-controlled banks are more efficient than privately-owned ones, due to government-controlled banks possessing larger market shares $(5.17 \%)$ than the average level $(2.28 \%)$ and a lower degree of diversification (25.75\%) than the average level (28.19\%). Consistent with the previous results of this study and the argument of La Porta et al. (2002), monopoly power frequently has accompanied productivity. As a response to the challenge of an intense competitive financial market, bank privatization has been viewed as a way to improve the cost efficiency of government-controlled banks.

Finally, the estimated OSE scores of total banks are larger than 1 significantly. All banks are operating at increasing returns to scale (IRS), implying that the banks' current scale smaller than efficient scale and suggesting that expanding their production scale is necessary to decrease long-term average costs for achieving 
scale economies. In addition, the cost complementarities of all banks are positive significantly, indicating that the outputs, investments and loans, are related to the lack of diversified economic characteristics.

Table 4. Measures of cost efficiency, scale economies and cost complementarity

\begin{tabular}{|c|c|c|c|}
\hline Banks (numbers) & Cost efficiency ${ }^{a}$ & Scale economies ${ }^{b}$ & Cost complementarity ${ }^{a}$ \\
\hline \multirow[t]{2}{*}{ Total banks (44) } & 0.7773 & 1.1397 & $2.06 \mathrm{E}-10$ \\
\hline & $(0.3278)$ & $(0.3188)$ & $(2.80 \mathrm{E}-10)$ \\
\hline \multirow[t]{2}{*}{ Merging banks (11) } & 0.6954 & 1.1101 & $2.09 \mathrm{E}-10$ \\
\hline & $(0.5025)$ & $(0.2894)$ & $(2.33 \mathrm{E}-10)$ \\
\hline \multirow[t]{2}{*}{ Pre-M\&As } & 0.7459 & 1.1040 & $2.45 \mathrm{E}-10$ \\
\hline & $(0.3870)$ & $(0.2823)$ & $(2.30 \mathrm{E}-10)$ \\
\hline \multirow[t]{2}{*}{ Post M\&As } & 0.5718 & 1.1297 & $9.50 \mathrm{E}-11$ \\
\hline & $(0.6837)$ & $(0.3161)$ & $(2.06 \mathrm{E}-10)$ \\
\hline \multirow[t]{2}{*}{ Target banks (11) } & 0.7624 & 1.0953 & $2.30 \mathrm{E}-10$ \\
\hline & $(0.3291)$ & $(0.2686)$ & $(2.22 \mathrm{E}-10)$ \\
\hline \multirow[t]{2}{*}{ Banks to credit union mergers (19) } & 0.7603 & 1.1418 & $1.88 \mathrm{E}-10$ \\
\hline & $(0.4002)$ & $(0.3153)$ & $(2.80 \mathrm{E}-10)$ \\
\hline \multirow[t]{2}{*}{ Pre-M\&As } & 0.8835 & 1.1418 & $1.88 \mathrm{E}-10$ \\
\hline & $(0.0929)$ & $(0.4086)$ & $(2.41 \mathrm{E}-10)$ \\
\hline \multirow[t]{2}{*}{ Post M\&As } & 0.7178 & 1.1098 & $1.75 \mathrm{E}-10$ \\
\hline & $(0.4523)$ & $(0.2614)$ & $(2.95 \mathrm{E}-10)$ \\
\hline \multirow[t]{2}{*}{ Government - controlled banks (13) } & 0.8369 & 1.1476 & $2.29 \mathrm{E}-10$ \\
\hline & $(0.2767)$ & $(0.3432)$ & $(3.59 \mathrm{E}-10)$ \\
\hline \multirow[t]{2}{*}{ Privately - owned banks (31) } & 0.7533 & 1.1361 & $1.95 \mathrm{E}-10$ \\
\hline & $(0.3408)$ & $(0.3078)$ & $(2.37 \mathrm{E}-10)$ \\
\hline
\end{tabular}

Note. Numbers in parentheses are standard errors.

The estimated score of cost efficiency is from 0 to 1 and the cost efficiency is higher (lower) when the score is closer to 1(0), indicating that the actual total costs are closer to the optimization. The estimated score of scale economies is larger (less) than 1, indicating at the increasing (decreasing) returns to scale. The estimated score of cost complementarity is less (larger) than 0 , indicating that the cost complementarity exists.

${ }^{a}$ : The estimated cores of cost efficiency and cost complementarity are different from 0 significant at the 0.1 level. ${ }^{b}:$ The estimates score of economies scale is not different from 1 significant at $10 \%$, indicating that total banks are at increasing returns of scale.

\section{Conclusion}

This paper adopts the specific model of Battase and Coelli (1995) to investigate the impacts of acquisition targets, diversification and market power on cost efficiency simultaneously, and compare scale economies and cost complementarities for 44 domestic commercial banks in Taiwan during the period from 1997 to 2006.

The results are summarized as follows. First, both bank to bank mergers and bank to credit union mergers are negatively related to cost efficiency significantly, and furthermore, interbank mergers have a greater negative impact on cost efficiency than that of bank to credit union mergers. Second, the impact of diversification on cost efficiency is significantly negative, consistent with the prior studies (Rime \& Stiroh, 2003; Stiroh \& Rumble, 2006; Laeven \& Levine, 2007; Schmid \& Walter, 2009; Berger et al., 2010). Diversification costs outweigh benefits resulting in diseconomies of scale. Third, the market power is positive related to cost efficiency, consistent with the results of Maudo and Guevara (2007), allowing rejection of the quiet life hypothesis (Berger \& Hannan, 1998).

Banks with greater market power in loans can possess superior cost efficiency. Other control variables are corresponding with our expectations. Fourth, both bank to bank mergers and bank to credit union ones are less efficient in the post mergers. In addition, government-controlled banks are more efficient than privately-owned 
ones, mainly attributable to larger market power. Finally, all banks are operating at IRS, implying that it is necessary to expand production scale or market to reduce long-term average costs to achieve scale economies. The cost complementariness between investments and loans do not exist, resulting in the lack of diversified economic characteristics. Therefore, cost efficiency improvements of the banking sector can be generated by decreasing diversification and the NPL ratio or increasing market power of loans and financial development.

\section{Acknowledgments}

The authors are indebted to the Ministry of Science and Technology of the Republic of China, Taiwan, for their financial support of this research under grant number MOST 103-2410-H-264-002. The authors are also most grateful for two anonymous referee's valuable comments and constructive suggestions. Remaining errors are the responsibility of the authors.

\section{References}

Aigner, D. J., Lovell, C. A. K., \& Schmidt, P. (1977). Formulation and estimation of stochastic frontier production function models. Journal of Econometrics, 6, 21-37. http://dx.doi.org/10.1016/0304-4076(77)90052-5

Akhavein, J. D., Berger, A. N., \& Humphrey, D. B. (1997). The effects of mega mergers on efficiency and prices: Evidence from a bank profit function. Review Industrial Organization, 12, 95-139. http://dx.doi.org/10.1023/A:1007760924829

Al-Sharkas, A. A., Hassan, M. K., \& Lawernce, S. (2008). The impact of mergers and acquisitions on the efficiency of the U.S. banking industry: Further evidence. Journal of Business Finance \& Accounting, 35, 50-70. http://dx.doi.org/10.1016/S0378-4266(96)00014-3

Altunbas, Y., \& Marques, D. (2008). Mergers and acquisitions and bank performance in Europe: The role of strategic similarities. Journal of Economics and Business, 60, $204-222$. http://dx.doi.org/10.1016/j.jeconbus.2007.02.003

Battese, G. E., \& Coelli, T. J. (1995). A model for technical inefficiency effects in a stochastic frontier production function for panel data. Empirical Economics, 20, 325-332. http://dx.doi.org/10.1007/BF01205442

Berger, A. N. (1995). The profit-structure relationship in banking - test of market power and efficient-structure hypotheses. Journal of Money, Credit and Banking, 27, 404-431.

Berger, A. N., \& Hannan, T. H. (1998). The efficiency cost of market power in the banking industry: A test of the 'quiet life' and related hypotheses. Review of Economics and Statistics, 8, 454-465. http://dx.doi.org/10.1162/003465398557555

Berger, A. N., \& Humphrey, D. B. (1992). Megamergers in banking and the use of cost efficiency as an antitrust defense. Antitrust Bulletin, 33, 541-600.

Berger, A. N., Demsetz, R. S., \& Strahan, P. E. (1999). The consolidation of the financial services industry: Causes, consequences, and implications for the future. Journal of Banking \& Finance, 23, $135-194$. http://dx.doi.org/10.1016/S0378-4266(98)00125-3

Berger, A. N., Hasan, I., \& Zhou, M. (2010). The effects of focus versus diversification on bank performance: Evidence from Chinese banks. Journal of Banking \& Finance, 34, 1417-1435. http://dx.doi.org/10.1016/j.jbankfin.2010.01.010

Berger, P., \& Ofek, E. (1995). Diversification's effect on firm value. Journal of Financial Economics, 37, 39-65. http://dx.doi.org/10.1016/0304-405X(94)00798-6

Bodnar, G. M., Tang, C., \& Weintrop, J. (1997). Both sides of corporate diversification: The value impacts of geographic and industrial diversification. Working Paper, NBER.

Campa, J. M., \& Hernando, I. (2006). M\&As performance in the European financial industry. Journal of Banking \& Finance, 30, 3367-3392. http://dx.doi.org/10.1016/j.jbankfin.2006.06.006

Campa, J. M., \& Kedia, S. (2002). Explaining the diversification discount. Journal of Finance, 57, $1731-1761$. http://dx.doi.org/10.1111/1540-6261.00476

Clark, J. (1988). Economies of scale and scope at depository financial institutions: A review of the literature. Federal Reserve Bank of Kansas City Economic Review, 73, 16-33.

Coelli, T. J. (1995). Estimators and hypothesis tests for a stochastic frontier function: A monte carlo analysis. 
Journal of Productivity Analysis, 6, 247-268. http://dx.doi.org/10.1007/BF01076978

Cornett M. M., McNutt, J. J., \& Tehranian, H. (2006). Performance changes around bank mergers: Revenue enhancements versus cost reductions. Journal of Money, Credit and Banking, 38, 1013-1050.

De Guevara, J. F., Maudos, J., \& Perez, F. (2005). Market power in the European banking sector. Journal of Financial Service Research, 27, 109-137. http://dx.doi.org/10.1007/s10693-005-6665-z

DeLong, G. L. (2001). Stockholder gains from focusing versus diversifying bank mergers. Journal of Financial Economics, 59, 221-252. http://dx.doi.org/10.1016/S0304-405X(00)00086-6

DeYoung, R. (1993). Bank mergers, X-efficiency, and the market for corporate control. Managerial Finance, 23, 32-47.

DeYoung, R., Evanoff, D. D., \& Molyneux, P. (2009). Mergers and acquisitions of financial institutions: A review of the post-2000 literature. Journal of Financial Service Research, 36, 87-110. http://dx.doi.org/10.1007/s10693-009-0066-7

Diaz, B., Olalla, M., \& Azorfa, S. (2004). Bank acquisitions and performance: Evidence from a panel of European credit entities. Journal of Economics and Business, 56, 377-404. http://dx.doi.org/10.1016/j.jeconbus.2004.02.001

Diewert, W. E., \& Wales, T. J. (1987). Flexible functional forms and global curvature conditions. Econometrica, $55,43-68$.

Elsas, R., Hackethal, A., \& Marjus, H. (2010). The anatomy of bank diversification. Journal of Banking \& Finance, 34, 1274-1287. http://dx.doi.org/10.1016/j.jbankfin.2009.11.024

Graham, J. R., Lemmon, M. L., \& Wolf, J. (2002). Does corporate diversification destroy value?. Journal of Finance, 57, 695-720. http://dx.doi.org/10.1111/1540-6261.00439

Hannan, T. H., \& Pilloff, S. J. (2006). Acquisition targets and motives in the banking industry. Federal Reserve Board Finance and Economics Discussion Series, 2006 . http://dx.doi.org/10.1111/j.1538-4616.2009.00251.x

Houston, J., James, C., \& Ryngaert, M. (2001). Where do merger gains come from? Bank mergers from the perspective of insiders and outsiders. Journal of Financial Economics, 60, 285-331. http://dx.doi.org/10.1016/S0304-405X(01)00046-0

Hughes, J. P., Mester, L. J., \& Moon, C. G. (2001). Are scale economies in banking elusive or illusive? Evidence obtained by incorporating capital structure and risk-taking into models of bank production. Journal of Banking \& Finance, 25, 2169-2208. http://dx.doi.org/10.1016/S0378-4266(01)00190-X

Jagtiani, J., Nathan, A., \& Sick, G. (1995). Scale economies and cost complementarities in commercial banks: On- and off-balance sheet activities. Journal of Banking \& Finance, 19, 1175-1189. http://dx.doi.org/10.1016/0378-4266(94)00078-H

Knapp, M., Gart, A., \& Chaudhry, M. (2006). The impact of mean reversion of bank profitability on post-merger performance in the banking industry. Journal of Banking \& Finance, 30, 3503-3517. http://dx.doi.org/10.1016/j.jbankfin.2006.01.005

Kohers, T., Huang, M. H., \& Kohers, N. (2000). Market perception of efficiency in bank holding company mergers: The roles of the DEA and SFA models in capturing merger potential. Review of Financial Economics, 9, 101-120. http://dx.doi.org/10.1016/S1058-3300(00)00019-7

La Porta, R., Lo'pez-de-Silanes, F., \& Shleifer, A. (2002), Government ownership of banks. Journal of Finance, 57, 265-301. http://dx.doi.org/10.1111/1540-6261.00422

Laeven, L., \& Levine, R. (2007). Is there a diversification discount in financial conglomerates?. Journal of Financial Economics, 85, 331-367. http://dx.doi.org/10.1016/j.jfineco.2005.06.001

Lang, L. H. P., \& Stulz, R. M. (1994). Tobin's Q, corporate diversification, and firm performance. Journal of Political Economy, 102, 1248-1280. http://dx.doi.org/10.3386/w4376

Maudos, J., \& Ferna'ndez de Guevara, J. (2007). The cost of market power in banking: Social welfare loss vs. cost inefficiency. Journal of Banking \& Finance, 31, 2103-2125. http://dx.doi.org/10.1016/j.jbankfin.2006.10.028

Meeusen, W., \& Van Den Broeck, J. (1977). Efficiency estimation from Cobb- Douglas production functions with composed error. International Economic Review, 18, 435-444. 
Megginson, W. L. (2005). The economics of bank privatization. Journal of Banking \& Finance, 29, 1931-1980. http://dx.doi.org/10.1016/j.jbankfin.2005.03.005

Peristiani, S. (1997). Do mergers improve the X-efficiency of scale efficiency of U.S. banks? Evidence from the 1980s. Journal of Money, Credit and Banking, 29, 86-92.

Rajan, R. G., Servaes, H., \& Zingales, L. (2000). The cost of diversity: The diversification discount and inefficient investment. Journal of Finance, 55, 35-80. http://dx.doi.org/10.1111/0022-1082.00200

Rhoades, S. A. (1998). The efficiency effects of bank mergers- an overview of case studies of nine mergers. Journal of Banking \& Finance, 22, 273-291. http://dx.doi.org/10.1016/S0378-4266(97)00053-8

Rime, B., \& Stiroh, K. J. (2003) The performance of universal banks: Evidence from Switzerland. Journal of Banking \& Finance, 27, 2121-2150. http://dx.doi.org/10.1016/S0378-4266(02)00318-7

Scharfstein, D. S., \& Stein, J. C. (2000). The dark side of internal capital markets: Divisional rent-seeking and inefficient investment. Journal of Finance, 55, 2537-2564. http://dx.doi.org/10.1111/0022-1082.00299

Schmid, M., \& Walter, I. (2009). Do financial conglomerates destroy or create economic value? Journal of Financial Intermediation, 18, 193-216. http://dx.doi.org/10.1016/j.jfi.2008.07.002

Shaffer, S. (1993). Can mega mergers improve bank efficiency?. Journal of Banking \& Finance, 17, 423-436. http://dx.doi.org/10.1016/0378-4266(93)90042-C

Shepherd, W. (1982). Economies of scale and monopoly profits. In Craven, J.V. (Ed.), Industrial Organization, Antitrust, and Public Policy (pp. 165-204). Kluwer Nihoff, Boston.

Sherman, H. D., \& Rupert, T. J. (2006). Do bank mergers have hidden or foregone value? Realized and unrealized operating synergies in one bank merger. European Journal of Operational Research, 168, 253-268. http://dx.doi.org/10.1016/j.ejor.2004.05.002

Shin, H., \& Stulz, R. M. (1998). Are internal capital markets efficient? Quarterly Journal of Economics, May, $531-552$.

Srinivasan, A. (1992). Are there cost savings from bank mergers? Economic Review, Federal Reserve Bank of Atlanta, 77, 17-28.

Stein, J. C. (1997). Internal Capital markets and the competition for corporate resources. Journal of Finance, 52, 111-134. http://dx.doi.org/10.1111/j.1540-6261.1997.tb03810.x

Stiroh, K. J., \& Rumble, A. (2006). The dark side of diversification: The case of U.S. financial holding companies. Journal of Banking \& Finance, 30, 2131-2161. http://dx.doi.org/10.1016/j.jbankfin.2005.04.030

Teece, D. J. (1982). Towards an economic theory of the multiproduct firm. Journal of Economic Behaviour and Organization, 3, 39-63. http://dx.doi.org/10.1016/0167-2681(82)90003-8

Villalonga, B. (2004). Diversification discount or premium? New evidence from the business information tracking series. Journal of Finance, 59, 479-506. http://dx.doi.org/10.1111/j.1540-6261.2004.00640.x

Wang, H. J., \& Schmidt, P. (2002). One-step and two-step estimation of the effects of exogenous variables on technical efficiency levels. Journal of Productivity Analysis, 18, 129-144. http://dx.doi.org/10.1023/A:1016565719882

Weintraub, D. B., \& Nakane, M. I. (2005). Bank privatization and productivity: Evidence for Brazil. Journal of Banking \& Finance, 29, 2259-2289. http://dx.doi.org/10.1016/j.jbankfin.2005.03.015

Whited, T. M. (2001). Is it inefficient investment that causes the diversification discount? Journal of Finance, 56, 1667-1691. http://dx.doi.org/10.1111/0022-1082.00385

\section{Copyrights}

Copyright for this article is retained by the author(s), with first publication rights granted to the journal.

This is an open-access article distributed under the terms and conditions of the Creative Commons Attribution license (http://creativecommons.org/licenses/by/3.0/). 